\title{
ETNICITETI, NACIJE I GRANICE NA KORDUNU: PRIMJER BOŠNJAČKE NACIONALNE MANJINE
}

LANA PETERNEL

Institut za društvena istraživanja u Zagrebu

10000 Zagreb, Amruševa 11/2

lanapeternel@yahoo.com

FILIP ŠKILJAN

Institut za migracije i narodnosti

10000 Zagreb, Trg Stjepana Radića 3

filipskiljan@yahoo.co.uk
DOI: 10.17234/SEC.28.8

Izvorni znanstveni rad

Primljeno: 5. 4. 2016.

Prihvaćeno: 3. 5. 2016.

Ovaj rad nalazi se u otvorenom pristupu i može se distribuirati u skladu s odredbama licencije CC BY-NC-ND 4.0 HR

Cilj je ovog rada kroz različite i raznorodne podatke opisati migracije i konstrukciju identiteta doseljene populacije iz Bosne i Hercegovine na Kordunu. Također, cilj je prikazati grupne granice $i$ njihove strukture kao posljedice specifičnih povijesnih, socijalnih i političkih okolnosti. Identiteti doseljenika na Kordunu prikazani su kao kompleksni individualni i grupni ishodi koji formiraju različite strukture međugrupnih odnosa.

Ključne riječi: granice, etnicitet, migracije, poslijeratni kontekst, Kordun, Hrvatska, Bosna i Hercegovina

\section{UVOD}

O etnicitetu, etničkom i/ili nacionalnom identitetu napisan je nemali broj radova u kojima ih autori definiraju kao socijalno i kulturno konstruiranu kategoriju koja se ne temelji samo na objektivnim i mjerljivim kriterijima nego i na duboko internaliziranim te subjektivnim osjećajima $\mathrm{i}$ interpretacijama. Teško je i nabrojiti sve aktualne teoretske pristupe $u$ društvenim i humanističkim znanostima u kojima se društveni odnosi, procesi i promjene pokušavaju sagledati kroz fenomen etničkog identiteta ili etničnosti (manjinskog, većinskog, hibridnog, višestrukog i sl.) (Usp. Fenton 2010; Eriksen 2002; Banks 1999; Thompson 1989). Individualna ili kolektivna, subjektivna ili objektivna, povijesna ili aktualna karakteristika etniciteta omogućuje istraživačima da mu pristupaju ili kao markeru i 
prediktoru suvremenih društvenih procesa ili, sasvim suprotno, kao ishodu određenog konteksta i njegovih okolnosti. Procese u kojima se etnički identitet pojavljuje kao višedimenzionalna i promjenjiva psihološka, kulturna i socijalna odrednica ovisna o nestabilnim i rijetko pravovremeno definiranim okolnostima, opisujemo u ovom radu kroz etnografsku, povijesnu i demografsku perspektivu.

Kada bismo željeli izdvojiti definiciju koja opisuje etnicitet kao fenomen koji korespondira s našim pozicijama, vrijednostima $\mathrm{i}$ orijentacijama, bila bi to kratka antropološka definicija:

"Etnicitet [je] kao dio sebstva koji često prilično zbunjuje pojedinca, nešto nad čim on ili ona nemaju nadzor. U mjeri u kojoj je on duboko usađena emotivna sastavnica [identiteta], često se manje prenosi putem kognitivnog jezika ili učenja (na koje se sociologija gotovo u potpunosti ograničila) negoli putem procesa sličnih sanjanju i psihološkim prijenosima iz psihoanalitičkih seansi (Marcus i Fisher 2003:199).

Utemeljena na konstruktivističkom pristupu, ova definicija upućuje na internalizirane procese konstrukcije etniciteta koji podrazumijevaju prožimanje svjesnoga i nesvjesnoga te znanja i osjećaja isključivo na individualnoj razini. Međutim, paralele između individualnog i grupnog etniciteta te pitanja odnosa i granica ostaju izvan njezinih opisa. Stoga, prolazeći kroz subjektivne interpretacije etniciteta u određenom kontekstu, postavljamo pitanje koliko su grupni etniciteti odraz i ishodi nametnutih okolnosti, te korespondiraju li i u kojoj mjeri s individualnim etničkim orijentacijama. Danas u kontekstu suvremene migracijske krize, gdje putovnica, državljanstvo i etnička pripadnost garantiraju život izvan ili unutar bodljikavih žica, etnicitet kao koncept postaje ponovno iznimno važan antropološki analitički konstrukt, pogotovo u raspravama o akulturacijskim strategijama i orijentacijama stanovnika Hrvatske i Europe $\mathrm{s}$ jedne i migranata s druge strane.

\section{POKAZATELJI I POLAZIŠTA: DEFINICIJE I ODNOSI}

Jedinstveni pristup u istraživanju etniciteta kojije deskripciju kulturnih osobitosti pojedinih etničkih grupa nepovratno zamijenio s istraživanjem 
odnosa među njima jest Barthova konstrukcija etniciteta, etničkih grupa i granica objavljena gotovo prije pedeset godina (Barth 1969). Kako mnogi teoretičari tvrde, najupečatljiviji doprinos Barthova kratkoga uvodnog eseja jest odbacivanje nekritičkog povezivanja etniciteta s etničkom kulturom. Fokus je u njegovu radu na dinamičkoj upotrebi kulturnih markera $\mathrm{u}$ interaktivnom odnosu više zajednica različitih karakteristika i osobitosti (Fenton 2010:92). Etničke razlike ne nastaju zbog izolacije i nedostatka socijalne interakcije nego upravo suprotno, one su rezultat međugrupnih kontakata. Interakcija ne dovodi nužno do promjena i akulturacije; kulturne razlike opstaju usprkos međuetničkim kontaktima i međusobnoj ovisnosti (Barth 1969:10).

Propitivanju etniciteta koji se u mnogo elemenata oslanja na Bartha, pridonio je R. Jenkins (1997) stavljajući naglasak na ovisnosti etniciteta i kulture čija je sastavnica, te situacije u kojima se on proizvodi i reproducira. On pristupa etnicitetu kao procesu samodefiniranja određene situacije $u$ kojoj se nalazi pojedinac. Etnicitet je više varijabilan nego fiksan kulturni fenomen koji se temelji na dijeljenom zajedničkom značenju; istovremeno je produkt socijalne interakcije; točnije, dio je širega socijalnog identiteta kojeg ima svaki pojedinac; oblikuje se kroz dijalektičke odnose između sličnosti i različitosti (Jenkins 1997). Inspirirajući se Barthom, R. Jenkins u svom radu prikazuje "osnovni socijalnoantropološki model etniciteta" stavljajući naglasak na istraživanje i redefiniranje koncepta percepcije etničke (samo)identifikacije od strane drugih u odnosu na vlastitu i grupnu identifikaciju (Ibid.) naglašavajući kako je potrebno razmišljati kroz ideologije etničke identifikacije i odnosa između identiteta te srodnih identifikacija.

Antropolog Thomas H. Eriksen (2002) definira etnicitet kao aspekt društvenog odnosa koji podrazumijeva socijalnu reprodukciju osnovnih klasifikacijskih razlika među ljudima te aspekte dobiti i gubitka u socijalnoj interakciji. Etnicitet obuhvaća kulturno i političko značenje. Takva definicija izbjegava klasično popisivanje elemenata povezanih s kulturom ili društvom (jezik, religija i slično) te stavlja naglasak na činjenicu da je etnicitet pitanje odnosa i kontakta te posebice socijalne hijerarhije, tj. klasa. Samo ako se kulturne razlike smatraju važnima i ako postanu i društveno relevantne, samo tada društveni odnosi imaju i etnički karakter; drugim 
riječima, postoje situacije koje ne naglašavaju uvijek važnost etničkih odnosa na jednak način i jednakim intenzitetom nego je to posljedica neravnopravne distribucije moći (Ibid.).

Sociopsihološka istraživanja inspirirana su antropološkim pristupima te također uključuju različite analitičke kategorije temeljene na društvenom statusu i etnicitetu. Tako Berry i ostali(1999) uvode tipologiju akulturacijskih strategija koja razlikuje četiri tipa: asimilaciju, integraciju, segregaciju/ separaciju i marginalizaciju na osnovi dvaju različitih fenomena - kultura i grupa - u oba slučaja manjinskoj i većinskoj. Karakteristika je Berryjeve teorije (Berry 2001), bez obzira na individualni pristup u istraživanjima i metodologiji, kolektivistička dimenzija etniciteta te referiranje na grupne procese. Tipologija strategija temelji se na kulturi i zajednici te su ta dva fenomena u korelacijskim ili regresijskim odnosima, a individualni etnički identitet jest pokazatelj, indikator ili sadržaj akulturacijskih procesa (npr. Hutnik 1986; Phinney 1996, 2003; Phinney i ostali 2001, 2005). Tako fiksne kategorije većine i manjine, većinske i manjinske kulture sugeriraju klasičnu, čvrstu povezanost između etničkih identiteta i etničkih grupa, ne ostavljajući mnogo prostora za raspravu o kvaliteti i strukturi granica među ljudima. Međutim, krajnji ishodi istraživanja rezultiraju teorijom akulturacije koja pokazuje kako je akulturacija u različitim kulturnim i subjektivnim domenama pod utjecajem stupanja etničke identifikacije iznimno dinamičan, višeslojan i neprekinut proces kulturne transmisije.

Osim zavisnosti različitih kulturnih elemenata u definiranju etniciteta, najvažniju ulogu već dulje vrijeme imaju odnosi među ljudima, tj. konstruiranje granica. U antropologiji se simbolički i kognitivni aspekti granica mogu konceptualizirati na različite načine, ali postoje tri ključne razine značenja i definiranja koje navodi Barth (1999): 1) doslovno značenje, kada granice razdvajaju prostor, tj. teritorij; 2) apstraktno značenje koje uključuje prepreke ili ograničenja među socijalnim grupama i različitim akterima; 3) granice svijesti čovjeka kao obrasci dijeljenja i razdvajanja određenih etničkih kategorija (Barth 1999:17). Barth potvrđuje kako treba voditi računa da se koncept granica ne poistovjećuje s konceptom etničkih kategorija ili osjećajem pripadanja. Strukturiranje granica često uključuje sasvim različita kulturna značenja te treba izbjegavati pojednostavljivanje $\mathrm{i}$ linearno shvaćanje ovih kulturnih koncepata. Drugim riječima, etnicitet je 
osnovni koncept za nebirokratsko iscrtavanje granica socijalnih grupa (Ibid. 30), a iskustvo kulturnih različitosti među grupama jesu različiti shematski, tzv. kognitivni modeli koji se trebaju prikazati dinamički, uvažavajući širenje i postojanje različitih kulturnih varijacija (Barth 2002).

Strukturiranje dosadašnjih spoznaja o etnicitetu i granicama kroz sveobuhvatnu komparativnu analizu etniciteta i konstrukciju granica, koja uključuje teoretski diskurs ali i komparativne analize grupnih odnosa na sinkronijskoj i dijakronijskoj razini, prikazuje Wimmer u Ethnic Boundary Making: Institutions, Power, Networks (Wimmer 2013). Etnicitet u teoriji kroz povijest do danas karakterizira herderijanski pristup koji uključuje različite primordijalističke, instrumentalističke, esencijalističke, situacionističke i modernističke teze. Herderovo naslijeđe podrazumijeva "ahistorijski", "naturalistički" i esencijalizirani etnicitet koji se povezuje s jedinstvenom kulturom, socijalnim zajedništvom i zajedničkim identitetom (Ibid.). Prema Wimmeru, njihov je osnovni nedostatak što se etnicitet kao pojam pokušava empirijski i analitički spoznati ne postavljajući pitanje kako $i$ zašto etnicitet postaje iznimno važan u određenim društvima i kontekstima, ali ne i u drugima, i zašto je ponekad povezan s nejednakošću i isključivanjem, s političkom važnošću i javnim raspravama, te s čvrstom lojalnošću, dok u drugim slučajevima predstavlja sekundarni aspekt osobnog identiteta te ne podrazumijeva gotovo nikakvu političku angažiranost (Ibid. 3).

Wimmerova se paradigma zasniva na pomnije dizajniranim kategorijama već poznatih međugrupnih odnosa i granica naglašavajući važnost već spomenutih indikatora i kategorija poput samoidentifikacije kroz vrijeme i prostor. Ono po čemu su Wimmerove granice u teoriji složenije zasniva se na opisu procesa njihova nastajanja među zajednicama uzimajući u obzir slojevitost socijalnih, političkih, institucionalnih i kulturnih faktora (Wimmer 2008a:1044-1045). Etničke granice za njega su "kategorijalne" (klasifikacijske i simboličke) i "biheviorističke" (interakcijske i procesualne), a nastaju ekspanzijom (uključuje izgradnju nacionalnih država i etnogenezu), kontrakcijama (podrazumijeva iscrtavanje užih granica), transevaluacijom (ponovnim propitivanjem vrijednosti), prelascima granica i pozicioniranjem (odnosi se podjednako na grupu i pojedinca) te zamagljivanjem (smanjena važnost etniciteta 
kao osnovne kategorije u okviru socijalne organizacije). Kategorizacija i identifikacija granica temelje se na diskurzivnim i simboličkim izvorima, a zadržavaju se uz pomoć strategija diskriminacije. Značenje i lokacija granica mijenjaju se "političkom mobilizacijom" te "prisilom i nasiljem". Teoretski pristup Wimmera (2008a, 2009, 2013) karakterizira komparativna etnička perspektiva koja se provodi na više razina istodobno, individualnoj, grupnoj, političkoj itd. U njegovu pristupu središnje mjesto zauzima kontekst i dinamika kreiranja i/ili transformiranja etničkih grupa kroz različita razdoblja. Jednaka težina pridaje se demografskim i statističkim podacima, kao i subjektivnosti ili psihološkoj dimenziji.

Pokušavajući određenu strukturu etničkog identiteta staviti u kontekst vremena u kojem nositelji toga identiteta žive, u ovom radu krenuli smo od osnovnih migracijskih činjenica te prikazali osnovne koncepte etničke identifikacije. Inspirirajući se Wimmerovim konceptima (Wimmer 2008a:1045), krajnji je cilj kontekstualizacija i konceptualizacija procesa etničke samoidentifikacije kao indikatora etničkih granica. U ovom radu, osim konstruktivističkom idejama, nadahnuli smo se Wimmerovim radovima (2008a, 2008b, 2009, 2013) te smo postavili istraživačka pitanja: 1) Kako se konstruira etnička samoidentifikacija kao ishod dugogodišnjih tranzicijskih procesa i migracija na Kordunu kod stalno naseljenih stanovnika podrijetlom iz Bosne i Hercegovine?; 2) Može li etnička identifikacija Bošnjaka/Muslimana na Kordunu kao kompleksan kulturni, politički i povijesni konstrukt ovisan o različitim okolnostima doprinijeti razumijevanju o strukturi granica u svakodnevnom životu?

\section{BOŠNJACI/MUSLIMANI NA KORDUNU ${ }^{1}$}

Kada se govori o prostoru kao teritoriju, govori se i o njegovim granicama često u kontekstu modernih birokratskih država koje su osobito čvrste u vlastitoj ovisnosti o graničnim konceptima. Ako granice zamišljamo kao što ih Barth definira, kao mentalne "rubove" i "barijere" (Barth 1999:28), postoji vjerojatnost širokog raspona njihova značenja kroz različite interpretacije. Ako se u taj fizički koncept granica uvede i koncept

\footnotetext{
${ }^{1}$ Kordun (cordon - red, vrpca). Etimološki podrazumijeva niz graničnih utvrda ili vojni pojas.
} 
socijalnog pozicioniranja, "Pandorina kutija socijalnih i kognitivnih inventivnosti je otvorena" (Ibid.). Ono što nacionalni režimi žele kada učvršćuju svoje granice jest čvrsto odvajanje, jasna separacija i zaštita; međutim, tada usporedno počinju i one različite aktivnosti dozvoljenih i nedozvoljenih zamagljivanja, tj. pronalaženja različitih puteva i načina prelazaka.

Naše iskustvo fizičkih, čvrstih i administrativnih granica na Kordunu nije se dogodilo prelaskom administrativne granice na graničnom prijelazu nego potpuno slučajno i nenamjerno za vrijeme povratka s terenskog istraživanja na Kordunu uz granicu između Hrvatske i Bosne i Hercegovine. Naime, vozeći se navečer oko 20 sati neasfaltiranom cestom uz rijeku Glinu na hrvatskoj strani međudržavne granice, u društvu ključnog i iznimno zainteresiranog sugovornika za ovu problematiku, djelatnici Ministarstva unutarnjih poslova Republike Hrvatske zaustavili su našu crvenu Daciu. Tijekom terenskog istraživanja vodili smo se više principima brze etnografske procjene nego dugotrajnim sudioničkim promatranjem. Točnije, na terenu koji je trajao svega nekoliko dana, željeli smo razgovarati sa što većim brojem sugovornika što je uključivalo boravak u domovima sugovornika od ranog jutra do kasne večeri, a kako je zbog nadzora granice vožnja po noći (valjda) djelovala sumnjivo, "uhvaćeni smo na projektnom zadatku". Procedura provjere zbog potencijalnih nezakonitosti naših aktivnosti uključivala je izlazak iz automobila i njegov pretres (pregled prtljažnika i stvari u njemu, uključujući kompjutore, upitnike, diktafone i slično), davanje na uvid i provjeru osobnih dokumenata (osobne iskaznice i vozačke dozvole), te desetominutni "polustrukturirani intervju" o razlozima našeg kretanja. Nakon dvadesetak minuta zaključeno je kako od nas ne prijeti opasnost za državnu sigurnost, te smo se zaputili kuda smo i krenuli - prema domu našeg vidno uznemirenoga ključnog sugovornika. ${ }^{2}$

Razgovor s djelatnicima granične policije RH doživjeli smo prije svega kao zanimljiv izvor etnografskih podataka te kao specifično osobno

2 Ovo je istraživanje u potpunosti poduprto entuzijazmom i požrtvovnošću našega ključnog sugovornika kojem, nadamo se, barem jednim malim dijelom, na ovaj način duboko zahvaljujemo. Njegova motivacija za sudjelovanje zajedno s nama u terenskom radu bila je socijalna i politička zanemarenost Korduna te problemi ljudi koji tu usprkos svemu i dalje vole živjeti. 
iskustvo rada državnih institucija s ciljem čuvanja sigurnosti nacionalnog teritorija i ljudi koji na njemu žive. Zbog prirode posla koji radimo, službena procedura MUP-ovih djelatnika pobudila je još dublji interes za strukturu odnosa različitih aktera $\mathrm{i}$ institucija te stanovnika Korduna.

Opisali smo ovaj događaj jer mislimo kako zapravo na jedinstven način evocira sve one oblike granica koje želimo opisati. Možemo reći kako smo nas troje na terenu te večeri doživjeli sve Barthove granice doslovne, apstraktne te granice i naše svijesti o životu uz granice i preko granica. Naš je ključni sugovornik u intervjuu koji smo poslije s njim vodili detaljno opisao razliku između slobode kretanja na Kordunu danas i nekada, posebice prije rata kada je život na Kordunu u odnosu na Bosnu i Hercegovinu za neke izgledao kao "život s druge strane ceste".

Migracije koje su postale značajne sredinom 20. stoljeća obilježavaju prostor Korduna već pedesetak godina. ${ }^{3} \mathrm{U}$ početku su imale specifična obilježja ekonomskih, dok krajem prošlog stoljeća postaju sve intenzivnije potaknute etničkim nasiljem, diskriminacijom i ratom. O intenzitetu migracija prošlog stoljeća najbolje govori podatak da se, prema popisu kretanju stanovništva, u svega dva desetljeća, pedesetih i šezdesetih godina 20. stoljeća promijenila etnička slika pojedinih sela na Kordunu, posebice uz granicu s Bosnom i Hercegovinom. Demografski podaci pokazuju kako su Muslimani na Kordunu naseljavali mjesta uz samu granicu Bosne i Hercegovine i Hrvatske, te se taj prostor kroz kretanje i veze s jedne i druge strane granica doživljavao susjednim i bliskim. Ljudi su migrirali iz Cazinske krajine zbog neravnomjernog stupnja razvoja i infrastrukture toga područja u usporedbi s Kordunom kao razvijenijim susjednim područjem. Naime, nakon Cazinske bune ${ }^{4} 1950$. godine Cazinska se krajina nije i dalje razvijala u jednakoj mjeri kao i ostali dijelovi Bosne i Hercegovine. $\mathrm{Na}$ Kordun se doseljavalo uglavnom mlađe stanovništvo kao na primarno ali,

${ }^{3}$ Iz demografske perspektive migracijska kretanja stanovništva iz Bosne i Hercegovine na područje Korduna od kraja pedesetih godina 20. stoljeća do danas, kao i okolnosti u kojima su se odvijala, prikazana su detaljno u radu Bošnjaci/Muslimani na Kordunu 1991. i dvadeset godina kasnije - studija slučaja (Škiljan 2011).

${ }^{4}$ Cazinska buna zbivala se 1950. godine na području Cazinske krajine i na obližnjem Kordunu. Uzroci bune ležali su u velikim nametima države koje seljaci nisu mogli namiriti, a sudionici su bili uglavnom Muslimani (Škiljan 2011:6). 
nakon određenih godina provedenih na radu u inozemstvu, i sekundarno mjesto migracija.

Uspostavom samostalnih država i međudržavnih administrativnih granica status doseljenih Muslimana drastično se mijenja, ali postaje iznimno težak zbog ratnih okolnosti devedesetih u obje zemlje. Dio stanovništva, podjednako i domicilnog i doseljenog podrijetla, ostaje na Kordunu koji je početkom devedesetih okupiran i u sastavu tzv. Srpske autonomne oblasti (SAO) Krajine. Drugi dio stanovništva napušta domove i prelazi u Bosnu i Hercegovinu, a treći u neokupirane dijelove Hrvatske. Nakon mirne reintegracije Korduna i normalizacijom odnosa, Muslimani su morali dokazivati status državljana na osnovi prava stečenih prije rata u Hrvatskoj. Zbog različitih administrativnih prepreka problemi s kojima su se susretali bili su kategorizirani kao nemogućnost ostvarivanja prava na državljanstvo i prava na rad te problemi s dokazivanjem vlasništva nad imovinom. Drugi dio diskriminacije povezan je s ograničenošću slobode kretanja i percepcijom diskriminacije na vjerskoj osnovi (Škiljan 2011).

Bez obzira na prijavljen boravak dulji od pet godina u Republici Hrvatskoj, zasnovane radne odnose u hrvatskim poduzećima ili kroz vlasništvo nad tvrtkama i imovinom, status Bošnjaka/Muslimana ostaje vrlo kompleksan, pun kontroverznih odluka i odredbi. Odredba koja je omogućavala ostvarivanje prava na državljanstvo uključivala je vremensko ograničenje za predaju dokumenata, tako da se mnogi koji su živjeli izvan Hrvatske nisu pravovremeno uključili i predali zahtjeve za državljanstvo. To je dovelo do percepcije kako prijeratni stanovnici Korduna muslimanske/ bošnjačke nacionalnosti nisu tretirani jednako kao ostali povratnici hrvatske nacionalnosti nego da su namjerno diskriminirani u postupku dokazivanja svojih prava te da zbog toga nemaju osobne dokumente bez kojih ne mogu ostvariti pravo na rad, socijalno i mirovinsko osiguranje, kredit za obnovu kuća i imovine, pa čak i pravo na raspodjelu humanitarne pomoći (Ibid.). To potvrđuje i činjenica da zbog kompliciranih administrativnih procedura pripadnici bošnjačke/muslimanske zajednice uzimaju status trajno naseljenih stranaca umjesto državljana Republike Hrvatske. Također, praksa nije bila ujednačena tako da se događalo da jedan član obitelji dobije domovnicu, a ostali ne. Problemi stjecanja prava kao državljana Republike Hrvatske prikazani su i kroz razlike u ostvarivanju prava na 
različitim instancijama vlasti i u različitim teritorijalnim jedinicama (Ibid.). Naime, na bivšim okupiranim područjima procedura je bila daleko sporija i kompliciranija nego u većim mjestima i gradovima izvan Korduna. Različita prosvjedna pisma i dokumenti iz Mešihata Islamske zajednice u Hrvatskoj pokazuju broj Bošnjaka koji su se susreli s uskraćivanjem dokumenata o državljanstvu. ${ }^{5}$

Zahvaljujući političkoj mobilizaciji nacionalnih pitanja tijekom devedesetih definiranje etničke pripadnosti u novim okolnostima postaje iznimno složen proces, posebice na razini kolektivnog identiteta. Proces definiranja statusa Muslimana/Bošnjaka kao manjinske zajednice započeo je s uspostavom Republike Hrvatske, dakle, raspadom Jugoslavije i stjecanjem državne neovisnosti bivših federalnih republika. Muslimani, a poslije Bošnjaci u Sloveniji, Makedoniji i Hrvatskoj prestali su postojati kao konstitutivni narod bivše države, a nisu imali stečen status i prava nacionalnih manjina kao Mađari, Talijani te Česi i pripadnici tradicionalnih, tj. starih manjina (Ibid.). Tako Bošnjaci kao nova manjina nisu mogli ostvarivati pravo na političku zastupljenost u predstavničkom tijelu iako su bili najbrojnija nacionalna manjina poslije Srba (Čičak-Chand 1999:455).

\section{PITANJE ETNIČKOG IDENTITETA}

Svakodnevni život stanovnika Korduna zbog mnogobrojnih razloga, a bez obzira na administrativne, teritorijalne i čvrste međudržavne granice, uključivao je i dalje povezivanje sa susjednom regijom Bosne i Hercegovine. Kazivači su navodili da je većina i dalje prelazila međudržavnu granicu kompenzirajući nedostatke života u jednoj sredini prednostima u drugoj. Razlozi su intimne i praktične naravi: kupnja značajno jeftinije hrane, posebno cigareta, odlazak na groblje, posjet rodbini i tako dalje. Važno je spomenuti činjenicu da se na malograničnim prijelazima stanovništvu koje nije s područja one općine na kojoj se nalazi prijelaz naplaćivala određena taksa, te da su se ljeti i tijekom praznika stvarale gužve i višesatna čekanja na prijelaz.

$\mathrm{Na}$ Kordunu je službeni popis stanovništva prema etničkom identitetu izazvalo dosta prijepora i podjela zbog različitih interpretacija "ispravnog

5 Izvor: Otvoreno pismo dr. Šemse Tankovića, 2. runa 1998. Pismo Glas Amerike, $n / r$ Stevica Susa, www.sdah.hr/dokumenti/pismo10.doc. (pristup 8. 12. 2011.). 
znanja o vlastitom porijeklu". Prema popisu stanovišta iz 2001. godine, na Kordunu dio bivše muslimanske zajednice ${ }^{6}$ prihvaća nacionalni identitet Bošnjaka te se izjašnjava kao Bošnjaci, dok se drugi dio stanovništva podrijetlom iz Bosne i Hercegovine izjašnjava starom nacionalnošću, kao Muslimani. Drugim riječima, među stanovnicima Korduna zaživjeli su u usporednoj upotrebi Bošnjak kao "novi” i Musliman kao "stari” etnonim. Etnonim Bošnjak dobio je legitimitet i počeo se primjenjivati nakon Drugoga bošnjačkog sabora održanog 27. i 28. rujna 1993. u Sarajevu (Ibid. 455). Iz medijskog diskursa ${ }^{7}$ kao i iz razgovora sa sugovornicima u ovom istraživanju dosadašnji Muslimani bili su suočeni, osim s problemom regulacije pravnog statusa kao državljana Republike Hrvatske, i s problemom definiranja vlastite etničke pripadnosti (npr. Hadžijahić 1990; Isaković 1990; Balić 1994; Džaja 1994; Nanić 1999). Međutim, kategoriju "Musliman" Ustavni sud Republike Hrvatske ne priznaje, pa su građani koji su se tako izjasnili pribrojeni u kategoriju "Ostali", te su i stvarno ostali nevidljivi u okvirima svih regula u Republici Hrvatskoj. Kazivač je komentirao brisanje Muslimana iz popisa sljedećim riječima:

“... nemoguće [je] automatizmom prevoditi Muslimane u Bošnjake, jer bi to bio pravni presedan s nesagledivim posljedicama, [...] ono [se] može izvršiti samo individualno i [...] takvo rješenje nije moguće ..."

Administrativno spajanje bošnjačke i muslimanske zajednice s ciljem zajedničkog ostvarivanja prava iz Zakona o pravima nacionalnih manjina, tj. da zajednički biraju svoja vijeća i predstavnike nacionalnih manjina predložila je Bošnjačka nacionalna zajednica Hrvatske. Međutim, zbog bojazni da bi takvo spajanje stare i nove nacionalnosti trajno podijelilo bošnjački korpus u Republici Hrvatskoj na Bošnjake i Muslimane, od njega se odustalo. ${ }^{9}$ Stoga

${ }^{6}$ U popisu stanovništva 2001. godine 19677 građana Hrvatske izjasnilo se prethodnim nacionalnim imenom Bošnjaka Musliman (DZS 2001).

${ }^{7}$ Izvori u periodičkim izdanjima: Behar, br. 2, 1993.; br. 7, 1994.-1995.; br. 19-20, 1995.; Ljiljan, 5. srpnja 1995.; 10. siječnja 1996.; Novi list, 22. prosinca 1995.; Vjesnik, 25. kolovoza 1993.; 24.-26. prosinca 1997.

${ }^{8}$ Usp. Škiljan 2011.

9 Bošnjačka pismohrana, Zagreb, vol. 5/17-20, 2004.-2005., 317-321. http://www.bnz. hr/s15-dogaaji-u-bnzh/izdavacka-djelatnost/c44-pismohrana/pismohrana-2004-2005/ (pristup 8. 12. 2011.). 
se proces promjene etničkog naziva odvijao svojom dinamikom, usporedno na individualnoj i grupnoj razini, uključujući mnoga lobiranja, razgovore i uvjeravanja o ispravnoj etničkoj pripadnosti (Škiljan 2011).

Metodološki ovo istraživanje ima karakteristike brze etnografske procjene (Beebe 2014) više nego dubinskog intervjuiranja ili sudioničkog promatranja koje ovakva tematika zasigurno zaslužuje. U intervjuima koje smo provodili sudjelovala su oba autora ovog rada; intervjui su djelomično zapisivani, a djelomično snimani. Na osnovi analiza dogovora o etničkoj pripadnosti na Kordunu potvrdila se usporedna upotreba Musliman i Bošnjak, bez obzira na administrativne promjene i vremenski odmak, ali također prisutan je i etnonim Bosanac. "Dok nije došlo da se iskazuje kao Bošnjak, ja sam se osjećao kao Musliman. Sada sam Bošnjak.”; "Ja sam Musliman i ne smeta mi veliko M."; "Ja bih najviše volio biti Bosanac."10 Ovaj posljednji upotrebljava se najrjeđe i najmanje je zastupljen kao etnonim na Kordunu.

Svi kazivači duboko i detaljno su objašnjavali zašto osjećaju pripadnost Bošnjacima odnosno Muslimanima najčešće kroz interpretaciju povijesne etnogeneze: "Bošnjaci su postojali i prije hiljadu godina. Oni su stari koliko i Hrvati. Kada kažu da su Muslimani to je isto tako kao da Hrvati kažu za sebe da su katolici."; "Borili smo se za to da budemo Muslimani, a Bošnjaci su bili prije 300 godina u istočnoj Bosni” (Škiljan 2011).

Vjera ima važnu ulogu u konstrukciji identiteta, pa je i u tom pogledu prisutna kao važan sadržaj etniciteta: "Mi smo po vjeroispovijedi muslimani, a po naciji Bošnjaci” (Ibid.).

Više indikator identifikacije nego sadržaj etniciteta jest institucijska odluka te zakoni koji administrativno reguliraju identifikaciju: "Bio sam Musliman i ostao bih da nije zakon da moram biti Bošnjak" (Ibid.).

Emotivni aspekti identifikacije i komunikacije upućuju na sljedeće: ljutnju - "Kad ja ljudima kažem [...] oni se ljute.", uznemirenost - "Mene to jako muči.", i zbunjenost - “... ne znam se pravo odlučiti, trebao bi netko [...] objasniti" (Ibid.).

Također, kroz percepciju utjecaja političkih institucija naglašavaju se instrumentalističke strategije u identifikaciji: "Ipak, najviše ima

${ }^{10}$ Detaljnije etnografske citate i kontekst istraživanja usporediti u: Škiljan 2011. 
materijalista koji su uz onoga od kojeg imaju financijske koristi."; "To mi donosi privilegije i na taj sam način priznat" (Ibid.). S tim da je važno naglasiti kako su "privilegije" na Kordunu mogu definirati vrlo široko. Na pitanje zašto se vode takvim strategijama, odgovoreno nam je: "Ljudi moraju biti politički podobni” (Ibid.).

Koliko je etnicitet fenomen koji se djelomično "prenosi putem kognitivnog jezika ili učenja" (Marcus i Fisher 2003:199) dokazuje i sljedeći citat: "Trebao bi netko doći u selo našima i objasniti im što su Muslimani, a što su Bošnjaci."; objašnjenja poput "Ja sam Musliman, a Bošnjak mi je nešto skraćeno." očito nisu svima zadovoljavajuća opcija (Škiljan 2011).

U pogledu konstrukcije odnosa među grupama također je zadržana struktura grupnih granica koja podrazumijeva dihotomiju mi - oni, ali ne samo na Kordunu, tj. Muslimani - Bošnjaci u Hrvatskoj, nego i prema Bošnjacima u Bosni i Hercegovini. "Ja se izjašnjavam kao Musliman, a ne kao Bošnjak, [jer] Bošnjaci su svi u Bosni” (Ibid.).

Međutim, procesi koji kontekstualiziraju identifikaciju pokazuju kako su grupna razgraničenja na manifesnoj razini ukorijenjena u političkim opredjeljenjima još iz devedesetih godina prošlog stoljeća. Ispitanici koji su se smatrali političkim pristalicama tzv. autonomaške politike Fikreta Abdića, izjašnjavali su se kao etnički Muslimani, za razliku od kazivača koji su se osjećali kao manjina koja potječe iz Bosne i Hercegovine (a ne iz Autonomne pokrajine (AP) Zapadne Bosne) i koji su podržavali probošnjačku politiku Stranke demokratske akcije te se izjašnjavali kao Bošnjaci (Ibid. 22). Tako i dva desetljeća nakon rata u Bosni i Hercegovini vladaju stare podjele: "Kod nas je u selu podjela na autonomaše i one koji su za cjelovitu BIH." ili “Ovdje je 90\% ljudi uz Fikreta, a 10\% za zajedničku BIH.” Percepcija granica na etničkim kriterijima čak dolazi do izražaja prilikom zapošljavanja: "Oni koji se izjašnjavaju kao Muslimani mogu se lakše zaposliti kao radnici” (Škiljan 2011).

U antropologiji uvriježena kulturna domena kroz koju se propituju strukture granica često se definira kroz kulturne običaje primjerice odabira životnog partnera/partnerice. U ovom su istraživanju odgovori, kao i sama suština toga pitanja, sugerirali povezivanje i komunikaciju, ili socijalnu distanciju s obzirom na najznačajniju kulturnu različitost utemeljenu na 
vjerskom identitetu. Naime, kod muslimanske/bošnjačke zajednice na Kordunu prevladavaju endogamni brakovi u smislu vjenčanja pripadnika iste religijske pripadnosti: "Miješani brakovi [muslimana i kršćana, op. a.] su uvijek loše završavali."; "Bio bih protiv toga da mi je dijete u miješanom braku. To ne može opstati. To su dva različita svijeta" (Ibid.). Pozivajući se na Berryjevu akulturacijsku teoriju (Berry 1999), možemo zaključiti da u kulturnoj domeni intimnih i obiteljskih odnosa te socijalnih distancija postoje separacijske strategije koje isključuju drugačiji vjerski identitet partnera/partnerice.

Kada bismo sukladno Wimmerovu pristupu (Wimmer 2013) htjeli pokazati na koji se način strukturiraju etničke granice na individualnoj i grupnoj razini, uvidjeli bismo četiri kategorije granica: 1) unutarnje granice ili granice svijesti - "ja nekad i danas"; 2) apstraktne granice u različitom rasponu: a) "mi - oni”" u muslimanskoj/bošnjačkoj zajednici, b) u odnosu na Bošnjake u Bosni i Hercegovini, c) u odnosu na Hrvate i Srbe.

Podjednako i individualna i grupna razina, socijalne distancije na Kordunu nimalo ne sugeriraju statičnu podjelu nego su kriteriji u opticaju povezani s političkim opredjeljenjima, uključenošću u različite institucije, osobnom i obiteljskom poviješću, socijalnim statusom i percepcijom podrške, mnogo prije nego uobičajenim indikatorima etniciteta. $U$ tom se kontekstu granice mogu povlačiti na svim razinama strukturirajući socijalne klase i kategorije koje samo u jednom svom obliku imaju objektivne nacionalne i etničke odrednice. Nejednakost koja se konstruira na prostoru Korduna među grupama, samo se u jednom svojem segmentu može objasniti etničkim elementima i to prema udaljenijim grupama; nažalost, ona je mnogo više produkt različitih administrativnih, političkih i socijalnih problema u prošlosti i danas koji u procesima pregovaranja i interpretacije među stanovnicima i dobiva etnički karakter.

\section{ZAKLJUČNO RAZMATRANJE}

Želimo naglasiti kako smo u ovom radu posegnuli za fragmentima mnogo opsežnijeg istraživanja koje je uključivalo daleko veći broj informacija i podataka vezanih uz problematiku naseljavanja na Kordunu (Škiljan 2011) s ciljem detaljnijeg opisivanja etničkih granica i etniciteta na području Korduna u sklopu suvremenih teorija. Nadalje, odgovori vezani 
uz etničku identifikaciju dobiveni su u intervjuima isključivo s muškarcima te ističemo da ovi podaci upućuju na procese, dinamiku i činjenice koji ih formiraju, bez ikakve sugestije o točnosti ili ispravnosti pojedine identifikacijske strategije.

Naime, tijekom terenskog istraživanja, bez obzira na to koliko smo pokušali u razgovor uključiti žene, najčešće supruge naših kazivača, u tome u potpunosti nismo uspjeli. Drugim riječima, ni u jednom segmentu našeg razgovora sa sugovornicima gdje su i bile prisutne žene, nije ih se moglo ravnopravno uključiti u intervju, a da ih se pritom ne dovedemo u neugodnu situaciju koja podrazumijeva nedvosmislenu demonstraciju čvrstih rodnih granica, uloga i pozicija. Naime, autoritet u ovoj temi imaju isključivo i jedino muškarci. Istraživanje fenomena etniciteta iz ženske perspektive zadatak je i dužnost antropologije, ali u sljedećem, precizno na tu temu fokusiranom istraživanju s pomnije razrađenim analitičkim i metodološkim instrumentarijem.

U istraživanjima lokalnog karaktera uvijek se postavlja pitanje lokalnog i regionalnog identiteta te zavičajnih veza koje bi prostoru i ljudima koje se uvodi $u$ istraživanje dali dodatno kulturno značenje i posebnost. U ovom istraživanju translokalne prakse kao i translokalni identiteti nisu isplivali kao relevantni. Razlog zasigurno leži u karakteru samih migracijskih procesa ali i sadašnjem životu i praksama, kao i u borbi za međusobnim priznavanjem te prepoznavanjem od strane državnih institucija. Detaljnije istraživanje translokalnih migracija zahtijevalo bi drugačije usmjereno istraživanje (Npr. Čapo i Halilovich 2013) iako bi se tek tada moglo govoriti u potpunosti o markerima identiteta iz različitih kulturnih repozitorija.

Granica kao određeni kulturni konceptualni model predstavlja određeni sindrom ideja, u rasponu od zamišljenih linija, do apstraktnog dijeljenja i razlikovanja u realitetu političkih i socijalnih organizacija, do predloška za konceptualizaciju različitih ideja distinktivnosti (Barth 1999:20) koju ljudi koriste u svakodnevnom definiranju međuljudskih i grupnih odnosa provocirajući pitanja kada, zašto te s kojim značenjem i posljedicama su granice konstruirane. Zadatak je antropologije, kako navodi Barth (1999), da što vjerodostojnije oponaša faze razvoja ljudskog znanja i motivacija kako bi otkrila povezanost i načini konstrukcije 
određenih kategorija i analitičkih konstrukata. Kada se otvori više prostora imaginaciji i varijabilnosti u kognitivnom definiranju kategorija, otvara se prostor za prepoznavanje i opis daleko više oblika nego što smo ih u stanju mi sami uvidjeti među ljudima. Točnije, to nam omogućuje da istražujemo mnogo kompleksnije odnose između kognitivnih, kulturnih reprezentacija i krajnjih ishoda te da se na kraju antropološki analiziraju procesi promjena (Ibid. 27).

U socioekonomskom smislu Kordun još uvijek zahtijeva posebnu državnu skrb s ciljem društveno-ekonomskog oporavka. ${ }^{11}$ Nejednakost između grupa na Kordunu samo djelomično leži u pravim distancijama na osnovi etničkih elemenata; dapače, korijen je u mnogim administrativnim, političkim i socijalnim problemima koji u procesima pregovaranja i interpretacije među stanovnicima i dobivaju etnički karakter. Socijalne karakteristike povezane su s visokom stopom nezaposlenosti cijele populacije, a posebice među onima koji ne mogu dobiti status državljana (Škiljan 2011).

S druge strane, odnos isključivanja kompenzira se i kroz solidarne prakse koje su u zajednici prisutne te umanjuju mnoge opisane probleme. Njih definira aktivnost i posvećenost problemima predstavnika islamske vjerske zajednice čija je uloga presudna u prevladavanju svakodnevnih izazova i zadataka. Skrb predstavnika Islamske zajednice u Hrvatskoj predstavlja amortizirajući i istinski društveno-organizacijski "servis" u nepovezanim dijelovima Korduna. Tako ključni sugovornik kroz svoju društvenu ulogu pomaže kad god treba oko zdravstvene skrbi, prijevoza, tumačenja administrativnih normi oko stjecanja socijalnih prava i slično.

U teorijskom smislu granice su već dulje vrijeme uvriježena metafora međuetničkih odnosa, ali zbog suvremenih migracijskih kretanja postaju sve zanimljiviji analitički, a ne samo simbolički ili mentalni koncepti. Bez obzira na osporavanje originalnosti teorije (Jenkins 2014), Wimmer je u svom radu naglasio činjenicu o multidimenzionalnosti svakoga gradivnog elementa etničke strukture, procesa prepoznavanja i identifikacije (Wimmer 2013). Mislimo kako je Wimmerov pristup (Ibid.) izbjegao čvrste formule, kroz složene strukture konstrukcije i dekonstrukcije opisujući često

${ }^{11}$ Izvor: www.hr.undp.org (pristup 2016.). 
nepredvidljive višeslojne promjene i procese na originalan način. Primjeri identifikacije koje navodimo na području Korduna upravo naglašavaju dinamiku transformacije etničkih kategorija te međuetničkih klasifikacija i odnosa uvažavajući principe ekspanzionizma, redukcije, zamagljivanja i političke prisile koje Wimmer strukturira u svom radu. Stoga smatramo kako fiksni prediktori u istraživanjima često potvrđuju dosadašnje etničke modele i teorije ili pomoću zavisnih i nezavisnih varijabli, ili pomoću njihove razgradnje, tj. dekonstrukcije, ali bez duboke analize konteksta nije moguće shvatiti takvu dinamiku, niti na površnoj razini.

Krajnji cilj ovog rada jest doprinos raspravi o tome kako se granice nejednakosti samo djelomično mogu objasniti etničkim ili kulturnim elementima. Bez obzira na to koliko je etnicitet uvijek prisutan, okolnosti u društvu, u dijalogu, kulturi ili statistici mijenjaju strukturu odnosa na manifesnoj razini. Na taj se način svakako dobiva kompletnija i kompleksnija društvena slika međuljudskih odnosa temeljenih na različitim političkim određenjima i međusobnom (ne)prepoznavanju u povijesnim ili suvremenim okolnostima. Ali opet nije dovoljno samo uvrstiti što je moguće veći broj socijalnih pojmova, kulturnih glasova, individualnih ideja ili činjenica iz prošlih i suvremenih okolnosti, nego je do kreiranja potpunije slike potrebno voditi računa i o onim često zanemarivanim i zbunjujućim romantičnim okolnostima iz individualne perspektive kao što navode Marcus i Fisher (2003), da se ne bi ispustilo iz vida kako je fragilna struktura etniciteta nevjerojatno čvrsta kada su u pitanju primjerice etničke distancije ili etnička diskriminacija.

Postupak opisivanja dinamične promjene upućuje na proces konstrukcije i prepoznavanja društvenih i kulturnih procesa te fenomena u prijašnjem obliku u vrijeme SFRJ kada je etnički, tj. nacionalni naziv Musliman obilježavao vjersku i etničku zajednicu u Hrvatskoj i u Bosni i Hercegovini, do današnjeg oblika nacionalnog identiteta Bošnjak na razini Ustava Republike Hrvatske. Svoju usporednu egzistenciju ipak na individualnoj razini u kontekstu osobne povijesti i identiteta dijele etnonimi Bošnjak, Musliman i Bosanac sugerirajući istost i različitost istodobno u okviru specifičnih okolnosti pozivajući se u isto vrijeme na svoje povijesno podrijetlo i ukorijenjeno kulturno znanje. Smatramo kako egzistencija ovih naoko zaboravljenih etnonima u javnoj raspravi ipak jest refleksija odnosa 
konstruiranih u prošlosti koje smo prikazali kroz statističke podatke i povijesne činjenice, i koji bez obzira na današnju marginaliziranost kreiraju specifične odnose unutar područja suvremenog Korduna.

\section{LITERATURA I IZVORI}

BALIĆ, Smail. 1994. Kultura Bošnjaka. Muslimanska komponenta. Tuzla: PP “R \& R”.

BANKS, Marcus. 1999. Ethnicity: Anthropological Concept. New York: Routledge.

BARTH, Fredrik, ur. 1969. Ethnic Groups and Boundaries: The Social Organization of Culture Difference. Boston: Little, Brown \& Company.

BARTH, Fredrik. 2000. "Boundaries and Connections". U Signifying identities: anthropological perspectives on boundaries and contested values, ur. Anthony P. Cohen. London: Routledge, 17-36.

BARTH, Fredrik. 2002. "An Anthropology of Knowledge". Current Anthropology, vol. 43:1-18. https://doi.org/10.1086/324131

BEEBE, James. 2014. Rapid Qualitative Inquiry: A Field Guide to Team-Based Assessment. Lanham: Rowman \& Littlefield.

BERRY, John W. 2001. “A Psychology of Immigration”. Journal of Social Issues, vol. 57/3:615-631. https://doi.org/10.1111/0022-4537.00231

BERRY, John W., Ype H. POORTINGA, Marshall H. SEGALL i Pierre R. DASEN. 1999. Cross-Cultural Psychology: Research and Applications. New York: Cambridge University Press.

ČAPO, Jana i Hariz HALILOVICH. 2013. "Lokaliziranje transnacionalizma: bosanske i hrvatske prekogranične prakse". U Hrvatska svakodnevica: etnografije vremena i prostora, ur. Jasna Čapo i Valentina Gulin Zrnić. Zagreb: Institut za etnologiju i folkloristiku, 221-241.

ČIČAK-CHAND, Ružica. 1999. "Islam i muslimani u Hrvatskoj: skica stvaranja muslimanskog/bošnjačkog sociokulturnog prostora". Migracijske i etničke teme, vol. 15/4: 451-464. http://hrcak.srce.hr/109478

DŽAJA, Srećko M. 1994. "Bosna i Bošnjaci u hrvatskom političkom diskursu”. Erasmus, vol. 9:33-41.

ECKLUND, Elaine H. 2005. “'Us' and 'Them': The Role of Religion in Mediating and Challenging the 'model minority' and Other Civic Boundaries". Ethnic and Racial Studies, vol. 28/1:132-150. https://doi.org/10.1080/0141987042000280049

ERIKSEN, Thomas H. 2002. Ethnicity and nationalism. London: Pluto Press.

FENTON, Steve. 2010. Ethnicity. Cambridge: Polity Press.

HADŽIJAHIĆ, Muhamed. 1990. Od tradicije do identiteta. Geneza nacionalnog pitanja bosanskih muslimana. Zagreb: Islamska zajednica. 
HUTNIK, Nimmi. 1986. "Patterns of Ethnic Minority Identification and Models of Social Adaptation". Ethnic and Racial Studies, vol. 9/2:150-167. https://doi.org/10.1080 $\underline{\text { O01419870.1986.9993520 }}$

ISAKOVIĆ, Aljoša, prir. 1990. O “nacionaliziranju” Muslimana. Zagreb: Globus.

JENKINS, Richard. 1997. Rethinking ethnicity: Arguments and Explorations. London: Sage Publications.

JENKINS, Richard. 2014. "Time to Move Beyond Boundary Making”. Ethnic and Racial Studies, vol. 37/5:809-813. https://doi.org/10.1080/01419870.2013.871308

LIEBKIND, Karmela, Tuuli Anna MÄHÖNEN, Sirkku VARJONEN i Inga JASINSKAJALAHTI. 2016. "Acculturation and identity". U The Cambridge Handbook of Acculturation Psychology. Ur. David L. Sam i John W. Berry. Cambridge: Cambridge University Press, 30-49.

MARCUS, George E. i Michael M. J. FISCHER. 2003. Antropologija kao kritika kulture. Zagreb: Naklada Breza.

NANIĆ, Faris. 1999. Tjeskoba vremena. Vrijeme rata i tranzicije 1989. - 1999. Zagreb: Profil international.

Narodnosni i vjerski sastav stanovništva Hrvatske 1880. - 1991. po naseljima, sv. 5. 1998. Zagreb: Državni zavod za statistiku (DZS).

PHINNEY, Jean S. 1996. "Understanding ethnic diversity: The role of ethnic identity". American Behavioural Scientist, vol. 40/2:143-152. https://doi. org/10.1177/0002764296040002005

PHINNEY, Jean S. 2003. "Ethnic identity and acculturation”. U Acculturation: advances in theory, measurement, and applied research, ur. Pamela Balls Organista, Kevin M. Chun i Gerardo Marín. Washington, DC: American Psychological Association, 63-82.

PHINNEY, Jean S., Gabriel HORENCZYK, Karmela LIEBKIND i Paul VEDDER. 2001. "Ethnic identity, immigration, and well-being: An interactional perspective". Journal of Social Issues, vol. 56/3:493-510. https://doi.org/10.1111/0022$\underline{4537.00225}$

PHINNEY, Jean S, Tina KIM-JO, Osorio SALONIKI i Perla VILHJALMSDOTTIR. 2005. "Autonomy and relatedness in adolescent-parent disagreements: Ethnic and developmental factors". Journal of Adolescents Research, vol. 20/1:8-39. https:// doi.org/10.1177/0743558404271237

Popis stanovništva, kućanstva i stanova. 2001. Zagreb: Državni zavod za statistiku (DZS). Popis stanovništva, kućanstva i stanova. 2011. Zagreb: Državni zavod za statistiku (DZS).

ŠKILJAN, Filip. 2011. "Bošnjaci/Muslimani na Kordunu 1991. i dvadeset godina kasnije - studija slučaja”. http:/www.associationforhistory.com/documents/golubic-2011/ golubic-2011-filip-skiljan.pdf (pristup 1. 2. 2016.). 
THOMPSON, Richard H. 1989. Theories of Ethnicity. A Critical Appraisal. New York: Greenwood Press.

WIMMER, Andreas. 2008a. "Elementary Strategies of Ethnic Boundary Making”. Ethnic and Racial Studies, vol. 31/6:1026-1055. https://doi. org/10.1080/01419870801905612

WIMMER, Andreas. 2008b. "The Making and Unmaking of Ethnic Boundaries: A Multilevel Process Theory”. American Journal of Sociology, vol. 113/4:970-1022. https://doi.org/10.1086/522803

WIMMER, Andreas. 2009. "Herder's Heritage and the Boundary-Making Approach: Studying Ethnicity in Immigrant Societies". Sociological Theory, vol. 27/3:244270. https://doi.org/10.1111/j.1467-9558.2009.01347.x

WIMMER, Andreas. 2013. Ethnic Boundary Making: Institutions, Power, Networks. Oxford: Oxford University Press.

Lana Peternel i Filip Škiljan

\section{ETHNICITIES, NATIONS AND BOUNDARIES IN KORDUN: AN EXAMPLE OF BOSNIAK ETHNIC MINORITY}

The main goal of this study is to describe migrations and identity construction of migrant population from Bosnia and Herzegovina in Kordun using different ethnographic and historical data. Furthermore, the goal is to show the group boundaries and their structure as the consequence of specific historical, social and political context. Migrant identities in Kordun are described as complex individual and group outcomes that form different structures of inter and intra - group relationships.

Keywords: boundaries, ethnicity, migrations, post-war context, Kordun, Croatia, Bosnia and Herzegovina

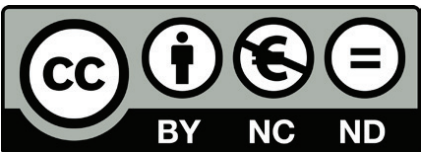

Articles published in this journal are Open Access and can be distributed under the terms and conditions of the Creative Commons license Attribution-NonCommercial-NoDerivatives 4.0 (http://creativecommons.org/licenses/by-nc-nd/4.0/) 